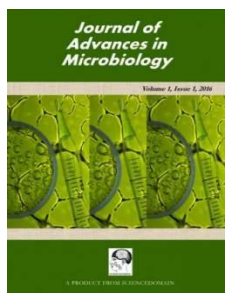

\title{
Asymptomatic Carriers of Enteric Pathogens and the Risk Factors among Food Handlers in a Rural Setting in Nigeria
}

\author{
A. N. Umo ${ }^{1^{*}}$ and A. O. Okon ${ }^{2}$ \\ ${ }^{1}$ Department of Medical Microbiology and Parasitology, College of Health Sciences, University of Uyo, \\ Nigeria. \\ ${ }^{2}$ Department of Animal and Environmental Biology, Faculty of Science, University of Uyo, Nigeria.
}

\section{Authors' contributions}

This work was carried out in collaboration between both authors. Author ANU conceptualized the study, did literature search, wrote the study protocol and part of the manuscript. Author AOO did the literature search, wrote part of the manuscript and carried out statistical analyses. Both authors read and approved the final manuscript.

Article Information

DOI: $10.9734 / \mathrm{JAMB} / 2017 / 34060$

Editor(s):

(1) Niranjala Perera, Department of Food Science \& Technology, Wayamba University of Sri Lanka, Sri Lanka.

Reviewers:

(1) Ohanu Eke Martin, University of Nigeria, Nigeria.

(2) Femi Ayoade, Redeemer's University, Nigeria.

(3) Shola Kola Babatunde, Kwara State University, Nigeria.

Complete Peer review History: http://www.sciencedomain.org/review-history/20064

Original Research Article

Received 11 ${ }^{\text {th }}$ May 2017

Accepted $8^{\text {th }}$ July 2017

Published $15^{\text {th }}$ July 2017

\section{ABSTRACT}

Introduction: Presence of enteric pathogens in humans has been described as one of the most common challenges of developing countries.

Materials and Methods: Stool samples were collected from 540 randomly selected workers in the hospitality industry in Etim-Ekpo and were subjected to microscopic and bacteriological examination to detect asymptomatic carriers of enteric pathogens. A structured questionnaire was used to collect additional data from the subjects. Each of these subjects aged between 18 and 56 years, gave informed oral consent before samples were collected.

Results: The results show presence of the following enteric bacterial pathogens: Salmonella sp, Shigella sp, Escherichia coli, Citrobacter $s p$ and Campylobacter sp. Intestinal parasites detected were ova of Ascaris lumbricoides, Hookworm, Taenia $s p$ and Trichuris trichuria, cysts of Entamoeba histolytica and Giardia lamblia. The distribution of the enteric pathogens was 
comparable among male and female subjects $(p>0.5)$. Putative risk factors that may have promoted transmission of these pathogens include poor personal hygiene habits, (OR $5.14,95 \% \mathrm{Cl}$ $1.66-10.62, p=0.01$ ), use of local stream/river as source of domestic water supply (OR $2.52,95 \%$ Cl 1.20-4.2, $p=0.01$ ) and poor sanitation with improper facility for sewage disposal (OR $4.49,95 \%$ $\mathrm{Cl} 2.61-4.21, \mathrm{p}=0.03$ ).

Discussion and Conclusion: The findings in this study bring to light the evidence that food handlers in some hospitality outlets in Etim-Ekpo are asymptomatic carriers of enteric pathogens. It is therefore advocated that food handlers in this area should be screened regularly and treated if found to harbor enteric pathogens. Promulgation and implementation of appropriate policies should be enforced in order to check the excesses of some food handlers and vendors.

Keywords: Asymptomatic carrier; enteric pathogen; food-handlers; Etim-Ekpo; risk factors.

\section{INTRODUCTION}

Foodborne illnesses are the major cause of personal distress, preventable death and avoidable economic burden. It may have more serious or long-term consequences and, most seriously, may be life threatening [1]. Food contamination may occur at any point during its journey through production, processing, preparation and distribution. The risk of food getting contaminated depends largely on the health status of the food handlers, their personal hygiene, knowledge and practice of food hygiene [2]. There are more than 250 different food borne diseases in world wide. Most of these diseases are infectious, caused by a variety of bacteria, viruses, and parasites. Other food borne illnesses can be poisonings, caused by harmful toxins or chemicals like poisonous mushrooms and enterotoxins of some bacteria. Possible etiologic agents for this are Salmonella, Campylobacter, Listeria, pathogenic Escherichia coli, Yersinia, Shigella, Enterobacter and Citrobacter [3]. These organisms may exist on food handler's skin, from which it may be transmitted to cooked moist protein-rich foods, and become intoxication agents if these foods are then kept for several hours without refrigeration or stored in containers [4]. Intestinal parasitic infections are of public health significance especially in the developing countries [5] and those that have direct life cycle, are transmitted by faecal-oral route to humans through poor personal hygiene [6,7]. These intestinal parasites and enteropathogenic bacteria can also be transmitted directly or indirectly through objects such as food, water, nails, fingers, to mention but a few. Compared to other parts of the hand, fingernails harbors most microorganisms and difficult to clean [8].

It is very common to find most food handlers located in various particular areas in the rural setting and some cities in Nigeria while some hawk from street to street. These types of food are most of the times not prepared under hygienic conditions. The costs of the food are usually very cheap and are mostly patronized by people in the lower socio-economic class. In addition, the environment could be very unhygienic.

Therefore, this study is aimed at determining the prevalence of enteric pathogenic bacteria and intestinal parasites, and the risk factors among food handlers working in food service establishments in a rural setting of Etim-Ekpo, Nigeria.

\section{MATERIALS AND METHODS}

A total of 540 single stool samples were collected between November, 2014 and June, 2015 from different apparently healthy food vendors selling food around various zones in Etim Ekpo local government area of Akwa Ibom State in the southern part of Nigeria. The areas covered were General Hospital, Etim Ekpo; Local Government Council Secretariat, Offiong market square and communities surrounding Obong University and Christian High School, Obong Ntak. Structured questionnaires were used to obtain data about their demographic parameters which include age, gender, source of water supply, and availability of toilet facilities. The samples were randomly collected and the subjects were each given sterile leak-proof labeled screwed capped universal containers after obtaining their permission (by explanation in the local dialect) to do so. All the samples were then transported to the Bacteriology and Parasitology laboratories of Medical Microbiology and Parasitology department, University of Uyo Teaching Hospital for processing and analysis. 


\subsection{Processing of Samples}

Samples were examined macroscopically for the following parameters: consistency, colour, presence of blood or mucus and presence of adult worm.

\subsubsection{Direct wet preparation}

The samples were analyzed using the direct microscopic method and Formol-acetone concentration method. Basically, a drop of fresh physiological saline was placed on one end of a clean glass slide and a drop of iodine on the other slide. With an applicator stick, a small amount of the sample was emulsified with the saline and a similar amount with the iodine to make thin smooth preparations. The two preparations were covered with cover slip and systematically examined for the presence of larvae, ciliates, helminthes eggs, cysts and oocysts using $10 x$ and $40 x$ objectives respectively.

\subsubsection{Formol-acetone concentration tech- niques}

About $1 \mathrm{~g}$ of stool sample was emulsified in about $10 \mathrm{ml}$ of $10 \%$ formol-water contained in a $15 \mathrm{ml}$ centrifuge tube. Formol-acetone concentration technique as described by Parija et al. [9] which substitutes acetone in place of ether was followed to prepare the faecal samples for microscopic examination.

\subsection{Isolation and Identification of Bacteria Species}

All the samples were inoculated into MacConkey agar (Difco), and Blood agar (Oxoid) plates. For the isolation of Shigella and Salmonella species, stool samples were first inoculated into Selenite $F$ broth (Oxoid, UK) and incubated for 24 hours at $37^{\circ} \mathrm{C}$ followed by subculture on Xylose Lysine Deoxycholate (XLD) (Oxoid) and SalmonellaShigella agar (Oxoid, UK). All the plates were incubated at $3^{\circ} \mathrm{C}$ for 24 hours and were examined for bacterial growth. Identification was done following standard procedures [10].

Data analysis was performed using SPSS version 17. Pearson's Chi square, $X^{2}$ test was used to determine the association between prevalence of infections with demographic and socioeconomic factors. Adjusted Odds ratios depending on different putative variables were calculated using logistic regression. Univariate analysis was used to identify risk factors associated with infections and variables that were significantly associated with the prevalence of infection were included in the multivariate analysis to identify risk factors for intestinal infections.

Ethical approval was obtained from the health authority of the Local Government Council.

\section{RESULTS}

The demographic parameters of the study population and the outcome of the results from the participants are indicated in Table 1. A total of 540 stool samples were collected from 129 (23.9\%) male and 411 (76.1\%) female food vendors. Out of the total number examined, 130 representing $24.1 \%$ were found to harbor various enteric pathogenic bacteria and intestinal parasites either as single or mixed infections. Female vendors infected were $21.11 \%$ compared to $2.96 \%$ of their male counterparts. A close look at the age distribution of the study participants reveals that participation were more in the 31-40 age bracket whereas the most infected age group $(10.92 \%)$ were those in the $21-30$ age bracket. Similarly, more of those working in small restaurants were in the majority of this study and consequently, $14.81 \%$ of them were infected. On the other hand, between $13.0-13.7 \%$ of those with poor personal habit and lifestyle were infected. On the whole, 5 enteric bacteria were isolated and they are Salmonella $s p$, Shigella $s p$, Escherichia coli, Campylobacter sp and Citrobacter sp while 6 intestinal parasites namely Ascaris lumbricoides, Hookworm, Trichuris trichuria, Entamoeba histolytica, and Giardia lamblia were recovered. The enteric bacteria and intestinal parasites isolated from the stool samples of the study participants are as shown in Table 2. The socio-demographic risk factors associated with infection among the study participants were examined using univariate analysis. The three risk factors as identified by both univariate and multivariate analyses in this study are personal lifestyle (which mostly involves not washing hands before food preparation) (OR=5.14; 95\% $\quad \mathrm{Cl}=1.66-10.62$; $p=0.01)$, use of pit toilet and bush for defaecation (OR=4.49; 95\% Cl=2.61-4.21; $p=0.03$ ), and use of local stream/river as source of domestic water supply $(\mathrm{OR}=2.52 ; 95 \% \quad \mathrm{Cl}=1.20-4.2 ; p=0.01)$. Using logistic regression, only those not using toilet $(\mathrm{OR}=3.13 ; 95 \% \mathrm{Cl}, \mathrm{p}=0.01)$ and not drinking boiled water $(\mathrm{OR}=2.73 ; 95 \% \mathrm{Cl}, \mathrm{p}=0.05)$ are more likely to suffer from infection. 
Table 1. Demographic parameters and prevalence of enteric bacteria pathogens among asymptomatic food vendors

\begin{tabular}{lll}
\hline Variable & $\mathbf{N}(\%)$ & No. positive (\%) \\
\hline Gender: & & \\
Female & $411(76.1)$ & $114(21.11)$ \\
Male & $129(23.9)$ & $16(2.96)$ \\
Age (years) & $36(6.67)$ & \\
$\leq 20$ & $161(29.81)$ & $59(4.63)$ \\
$21-30$ & $174(32.22)$ & $29(5.37)$ \\
$31-40$ & $117(21.67)$ & $6(1.11)$ \\
$41-50$ & $52(9.63)$ & $11(2.04)$ \\
$>50$ & & \\
Job area & $39(7.22)$ & $27(5.0)$ \\
Hawkers & $455(84.26)$ & $80(14.81)$ \\
Small restaurant & $46(8.52)$ & $23(4.26)$ \\
Bukars (Mama put) & & \\
Years involved in job area & $111(18.23)$ & $28(5.19)$ \\
$1-5$ & $390(64.04)$ & $67(12.40)$ \\
$6-10$ & $108(17.73)$ & $35(6.48)$ \\
$10 \&$ above & & \\
Personal Habit/Lifestyle & & \\
Handwash before food preparation: & $153(28.33)$ & $46(8.51)$ \\
Yes & $368(68.15)$ & $70(13.0)$ \\
No & $19(3.52)$ & $14(2.59)$ \\
Not Too Sure & & \\
Handwash after visiting the toilet: & $187(34.63)$ & $52(9.63)$ \\
Yes & $348(64.44)$ & $74(13.7)$ \\
No & $5(0.93)$ & $4(0.74)$ \\
Not Too Sure & $172(31.84)$ & $18(3.33)$ \\
System of Defaecation & $352(65.19)$ & $102(18.89)$ \\
Flush toilets & $16(2.96)$ & $10(1.85)$ \\
Pit toilets & & \\
Others (Bush etc) & $26(4.81)$ & $6(1.11)$ \\
Source of Domestic Water supply & $366(67.78)$ & $29(5.37)$ \\
Public Pipeborne water & $148(27.41)$ & $95(17.59)$ \\
Bore-hole water & & \\
Local stream/river & & \\
\hline
\end{tabular}

Table 2. Enteric bacteria pathogens and intestinal parasites isolated from stool samples of asymptomatic food vendors

\begin{tabular}{lll}
\hline Organisms isolated & Frequency of isolation & Percentage \\
\hline Enteric bacteria & & \\
Campylobacter $s p$ & 3 & 0.56 \\
Escherichia coli & 10 & 1.85 \\
Shigella $s p$ & 12 & 2.22 \\
Salmonella $s p$ & 5 & 0.93 \\
Citrobacter $s p$ & 7 & 1.29 \\
Total & 37 & 6.85 \\
Intestinal parasite & & \\
Hookworm & 59 & 10.93 \\
Ascaris lumbricoides & 24 & 4.44 \\
Trichuris trichuris & 17 & 3.15 \\
Taenia sp & 21 & 3.89 \\
Entamoeba histolytica & 36 & 6.67 \\
Giardia lamblia & 14 & 2.59 \\
Total & 171 & 31.67 \\
\hline
\end{tabular}




\section{DISCUSSION AND CONCLUSIONS}

The spread of disease through food-handlers is a common and persistent problem worldwide and food handlers may be carrying a wide range of enteropathogens and have therefore been implicated in the transmission of many infections to the public. Intestinal parasitic and enteric infections are public health problems especially in the developing countries. Studies indicate that intestinal parasitic infections result in malnutrition, morbidity, mortality and socioeconomic impact owing to treatment cost and hospitalization [11]. In this study, the overall prevalence of enteric bacteria and intestinal parasitic infection was $24.1 \%$. This is considered a high incidence among handlers of food and consumable materials. It can be attributed to so many factors which create the opportunity for these food vendors to eventually become carriers of the pathogens around the area. Rufai et al. [12] in their study suggested that prevailing environmental conditions do support the transmission of wide range of intestinal parasites among food vendors.

Foods that are mostly hawked and sold around the streets include rice, beans, spaghetti, fish, salad and meat among others. Regardless of the attendant health risks, street foods remain very popular, especially among youths. These types of food are usually preferable because it is less expensive compared to those served in regular restaurants around town [13].

A closer look at the hand-washing practices of the study participants revealed significant results. Washing of hands after toilet was observed in $34.63 \%$ while this practice was not observed in $64.44 \%$ and unfortunately $13.7 \%$ of them were infected. This practice is in total disagreement with previous reports in Gondar town and therefore shows that there is a significant low level of awareness of the need for hand washing soon after a visit to the toilet which most often may result in poor hygienic practices among food vendors with attendant contamination of food. Use of pit toilet and bush for defaecation is one of the identified risk factor for infection. Lack of latrines and adequate sewage disposal facilities have been known to contribute to the spread of the infective stages of intestinal parasite thereby bringing about a widespread contamination of food [6]. In this study, source of domestic water supply is one of the public health risk factors of disease transmission. This supports earlier work by Egbuobi et al. [14] in Enugu. Generally, those in hospitality business have a responsibility to ensure that food provided to the consumer is safe, and that it does not become a vehicle in disease outbreak or in the transmission of communicable diseases. This is because contamination of food with parasitic eggs and cysts for example, especially those hawked by food vendors may also serve as a source of infection to consumers of such items [15]. Therefore health education programmes on food safety and hygiene must be strengthened to ensure food safety. Organized routine visits and inspection which also throws some enlightenment by health officers from the environmental health unit of the overseeing government sector may enhance the level of awareness among the food vendors. Promulgation and implementation of appropriate policies should be enforced in order to check the excesses of some food handlers and vendors.

\section{COMPETING INTERESTS}

Authors have declared that no competing interests exist.

\section{REFERENCES}

1. Food Code 2001. US Dept of Health and Human Services; Public Health Service; Food and Drug Administration. Washington DC 20204.

2. Mudey BA, Kesharwani N, Mudey AG, Goyal RC, Dawale AK. Health status and personal hygiene among food handlers working at food establishment around a rural teaching hospital in wardha district of Maharashtra, India. Global J Health. 2010; 2(2):198.

3. CDC: Foodborne illness report-United States. Annual Report. 2005;1-13.

Available:http://www.cdc.gov/ncidod/dbmd/ diseaseinfo/files/foodborne illness faq.pdf

4. Saeeda $\mathrm{AH}$, Hamid HH. Bacteriological and parasitological assessment of food handlers in the Omdurman area of Sudan. J Microbiol Immunol Infect. 2010;43(1): 70-3.

5. Umo $A N$, Atting $I A$, Udokainyang $A D$, Umana OU. Prevalence and Public Health implications of Intestinal parasites of Dogs in an Urban Area of Akwa Ibom State, South-South Nigeria. World Journal of Biomedical Research. 2014;1(2):12-16.

6. Ukoli FMA. Introduction to parasitology in tropical Africa. New York: John Wiley and Sons. 1990;15-18, 201-315. 
7. Kaferstein F, Abdussalam M. Food safety in the $21^{\text {st }}$ century. Bull World Health Organ. 1999;77(4):347-51.

8. Zaglool DA, Khodari YA, Othman RAM, Farooq MU. Prevalence of intestinal parasites and bacteria among food handlers in a tertiary care hospital. Niger Med J. 2011;52(4):266-70.

9. Parija SC, Bhattacharya S, Padhan P, Shivaprakash MR. Evaluation of formalinacetone sedimentation in the concentration of stool for intestinal parasites. Tropical Doctor. 2003;33:163-64.

10. Cowan ST, Steel KJ. Manual for the Identification of Medical Bacteria $\left(4^{\text {th }}\right.$ Edition). Cambridge University Press. London. 1985;217.

11. World Health Organization. Food Safety Foodborne Diseases and value chain management for food safety. "Forging links between Agriculture and Health" CGIAR on Agriculture and Health Meeting in WHO/HQ, 25 June; 2007.
12. Rufai AM, Awi WGDB. Prevalence of Human Gastrointestinal Parasitic Infections in Relation to $\mathrm{Hu}$ - man and Industrial Activities in Ramuoluemi Community, Rivers State. African Journal of Applied Zoology \& Envi-Ronmental Biology. 2006;8:62-66.

13. Winarno FG, Allan A. Street foods in developing countries. Food and Agriculture Corporate document Repository. Street Food Project Report. 1990;3.

14. Egbuobi RC, Nwagbaraocha MA, DikeNdudim JN, Okorie HM, Ogamaka IA, Egbuobi LN, et al. Incidence of Intestinal parasites among food handlers (Hawkers) around the University of Nigeria Teaching Hospital, Enugu State, Nigeria. Open Journal of Medical Microbiology. 2014;4: 23-28.

15. Umeche N. Parasite ova and cysts in fruits in Calabar, Nigeria. The Nigeria Journal of Parasit. 1991;12:85-87.

(c) 2017 Umo and Okon; This is an Open Access article distributed under the terms of the Creative Commons Attribution License (http://creativecommons.org/licenses/by/4.0), which permits unrestricted use, distribution, and reproduction in any medium, provided the original work is properly cited.

Peer-review history:

The peer review history for this paper can be accessed here: http://sciencedomain.org/review-history/20064 